\title{
Selection strategy of phage-displayed immunogens based on an in vitro evaluation of the Th1 response of PBMCs and their potential use as a vaccine against Leishmania infantum infection
}

Fernanda Fonseca Ramos ${ }^{1}$, Lourena Emanuele Costa ${ }^{1}$, Daniel Silva Dias ${ }^{1}$, Thaís Teodoro Oliveira Santos ${ }^{1}$, Marcella Rezende Rodrigues ${ }^{1}$, Daniela Pagliara Lage ${ }^{1}$, Beatriz Cristina Silveira Salles ${ }^{1}$, Vívian Tamietti Martins ${ }^{1}$, Patrícia Aparecida Fernandes Ribeiro ', Miguel Angel Chávez-Fumagalli', Ana Carolina Silva Dias²,

Patrícia Terra Alves ${ }^{2}$, Érica Leandro Marciano Vieira ${ }^{3}$, Bruno Mendes Roatt ${ }^{4}$, Daniel Menezes-Souza ${ }^{1,4}$, Mariana Costa Duarte ${ }^{1,4}$, Antonio Lúcio Teixeira ${ }^{1,3,5+}$, Luiz Ricardo Goulart ${ }^{2,6+}$ and Eduardo Antonio Ferraz Coelho ${ }^{1,4^{*}+}$

\begin{abstract} with subclinical or asymptomatic infection.

\footnotetext{
* Correspondence: eduardoferrazcoelho@yahoo.com.br

${ }^{\dagger}$ Equal contributors

'Programa de Pós-Graduação em Ciências da Saúde: Infectologia e Medicina

Tropical, Faculdade de Medicina, Universidade Federal de Minas Gerais, Av.

Prof. Alfredo Balena, 190, Belo Horizonte, Minas Gerais 30130-100, Brazil

${ }^{4}$ Departamento de Patologia Clínica, COLTEC, Universidade Federal de Minas

Gerais, Av. Antônio Carlos, 6627, Pampulha, Belo Horizonte, Minas Gerais

31270-901, Brazil

Full list of author information is available at the end of the article
}

Background: The development of a vaccine for the prevention of visceral leishmaniasis (VL) still represents a significant unmet medical need. A human vaccine can be found if one takes into consideration that many people living in endemic areas of disease are infected but do not develop active VL, including those subjects

Methods: In this study, a phage display was used to select phage-exposed peptides that were specific to immunoglobulin $\mathrm{G}(\mathrm{lgG})$ antibodies from asymptomatic and symptomatic VL patients, separating them from non-infected subjects. Phage clones presenting valid peptide sequences were selected and used as stimuli of peripheral blood mononuclear cells (PBMCs) obtained from both patients' groups and controls. Those with higher interferon-gamma (IFN- - )/interleukin (IL)-10 ratios were further selected for vaccination tests.

Results: Among 17 evaluated clones, two were selected, B1 and D11, and used to immunize BALB/C mice in an attempt to further validate their in vivo protective efficacy against Leishmania infantum infection. Both clones induced partial protection against the parasite challenge, which was evidenced by the reduction of parasitism in the evaluated organs, a process mediated by a specific T helper (Th) 1 immune response.

Conclusions: To the best of our knowledge, this study is the first to use a rational strategy based on in vitro stimulation of human PBMCs with selected phage-displayed clones to obtain new immunogens against VL.

Keywords: Phage display, Peripheral blood mononuclear cells, Antibodies, Immune response, Vaccine, Visceral leishmaniasis 


\section{Background}

Leishmaniases are diseases caused by the infection with Leishmania protozoan parasites, visceral leishmaniasis (VL) representing the most fatal form of the disease when untreated [1, 2]. The disease is caused by Leishmania donovani and Leishmania infantum, species which are characterized by parasite dissemination in organs such as the liver, spleen and bone marrow of the mammalian hosts $[3,4]$.

Since the treatment against VL is complex, including long therapeutic regimens, drug toxicity and high cost [5], a vaccine should be considered to prevent disease. It is known that patients who heal their infections develop a protective immunity against Leishmania, much in the same way as healthy subjects living in endemic areas of disease, and do not develop symptomatic VL [6]. The immune response associated with the protection is attributed to the development of a $\mathrm{T}$ helper (Th)1-type immunity, which is based on the production of cytokines, such as interferon-gamma (IFN- $\gamma$ ), tumor necrosis factor-alpha (TNF- $\alpha$ ), interleukin (IL)-12, granulocytemacrophage colony-stimulating factor (GM-CSF), among others, by $\mathrm{CD}^{+}$and $\mathrm{CD}^{+} \mathrm{T}$ cell subtypes. These molecules are capable of activating infected macrophages to produce nitric oxide (NO), which is responsible for intracellular amastigote death [7, 8]. By contrast, cytokines, such as IL-4, IL-10, IL-13, and transforming growth factor beta (TGF- $\beta$ ), inhibit the development of Th1 responses, allowing the occurrence of the active disease $[9,10]$.

In addition, peripheral blood mononuclear cells (PBMCs) collected from patients with subclinical or asymptomatic infection respond to stimulation with leishmanial antigens, producing IFN- $\gamma$ and IL-12. However, those developing acute VL present cells did not respond to stimulation with Leishmania antigens, nor did they proliferate and produce cytokines like IFN- $\gamma[6,11,12]$. In this context, this patient class presents high levels of IL-10, with the presence of enhanced IL-10 messenger ribonucleic acid (mRNA) expression in infected organs [13].

A vaccine candidate against VL should be able to induce long-lasting protective immunity in the mammalian hosts by inducing both $\mathrm{T}$ cell subtypes, which could be boosted by natural infections, thus reducing the number of doses necessary to guarantee protection against infection. In addition, this candidate should be effective against different Leishmania species, cheap and easy to produce [14]. However, these requirements are difficult to obtain, since most of the molecules tested are composed by immunogens that offer species-specific protection and present a high cost of production and/or a need to associate immune adjuvants to induce protection [15-18]. Regarding the use of adjuvants, the regulation of these compounds for humans is far more rigorous than those applied to veterinary vaccines, making it difficult to obtain a highly immunogenic composition to be used in these mammalian hosts [19].

Phage display is a high-throughput technology able to identify novel molecules to be used in immunological applications, such as vaccine candidates [20, 21], diagnostic markers [22, 23] and/or immunotherapeutic targets against diseases [24-26]. Regarding vaccines, phage molecules themselves act as immune adjuvants in the immunized mammalian hosts, eliminating the need to incorporate this product in the formulation [27, 28]. For instance, a vaccination protocol using two phage clones selected by antibodies in VL dog sera was performed in murine models, and both immunogens were protective against $L$. infantum or $L$. amazonensis challenge infection $[29,30]$. In these studies, no adjuvant was associated with the phages before their administration in $\mathrm{BALB} / \mathrm{c}$ mice, and these phages were considered to be immunogenic carriers of the foreign peptides present in the viral capsid. This strategy is deemed to be responsible for guaranteeing a protective immune response against the infection caused by distinct Leishmania species.

In this context, in the current study phage display technology was used to screen specific peptides against immunoglobulin G (IgG) antibodies derived from asymptomatic and symptomatic VL patients, which were separated from IgG purified from non-infected subjects. After the biopanning cycles, target peptides, called mimotopes, were used to stimulate PBMCs from noninfected subjects living in endemic areas of disease and from VL patients, aiming to select those able to induce higher levels of IFN- $\gamma$ and a lower production of IL-10, based on their calculated selectivity and specificity. Selected clones with the highest IFN- $\gamma / \mathrm{IL}-10$ ratios were used to immunize BALB/c mice, which were later challenged with $L$. infantum promastigotes. This new selection strategy presented here can be considered useful to identify vaccine candidates against VL, as it represents the first proof-of-concept for the discovery of novel immunogens able to induce specific Th1 responses through the use of phage-displayed peptides.

\section{Methods \\ Blood samples}

Peripheral blood samples were collected with (heparin) or without anticoagulant from non-infected subjects $(n=10$; 7 males and 3 females, ranging from 24 to 51 years in age) living in an endemic area of disease (Belo Horizonte, Minas Gerais, Brazil), and from VL patients. Non-infected subjects presented no clinical sign of disease at the moment of sample collection and showed negative serological results when the Kalazar Detect ${ }^{\mathrm{Tm}}$ Test (InBios ${ }^{\oplus}$ International, Seattle, USA) was applied. Symptomatic VL 
patients ( $n=10 ; 6$ males and 4 females, ranging from 22 to 56 years in age) presented anemia, hepatomegaly and splenomegaly, and were diagnosed by polymerase chain reaction (PCR), targeting L. infantum kinetoplastid deoxyribonucleic acid (kDNA) in their spleen and/or bone marrow aspirates. Asymptomatic VL patients $(n=7 ; 5$ males and 2 females, ranging from 27 to 49 years in age) showed positive serological and parasitological results when the Kalazar Detect ${ }^{\mathrm{TM}}$ Test and PCR technique, respectively, were applied; however, they presented no clinical signal of the disease.

\section{Biopanning cycles on phage display}

To perform the phage display technology, a purification of IgG antibodies of VL patients and healthy subjects sera was performed by coupling them onto magnetic microspheres conjugated to protein G (Dynabeads, Invitrogen, Carlsbad, California, USA), as described elsewhere [31]. To carry out the biopanning cycles, $10^{12}$ viral particles of the bacteriophage library, containing randomly constrained peptides fused to the pIII coat protein of M13 filamentous phages (Ph.D. ${ }^{\circledR}$-C7C library, New England BioLabs, Ipswich, Massachusetts, USA) were diluted in $250 \mu \mathrm{l}$ of a solution consisting of $50 \mathrm{mM}$ Tris$\mathrm{HCl} \mathrm{pH} \mathrm{7.5,} 150 \mathrm{mM} \mathrm{NaCl}$, and 0.1\% Tween 20 buffer (TBS-T). The mixture was incubated for $30 \mathrm{~min}$, at room temperature, with microspheres coupled to the purified IgG antibodies from healthy subjects for separation, which were magnetically captured. The remaining phages in the supernatant were recovered and transferred to a new tube, at which time they were submitted to positive selection using IgG of VL patients. The supernatant was removed, and the bound phages were washed five times in $1 \mathrm{ml}$ of TBS-T, at which time they were eluted in $500 \mu \mathrm{l} 0.2 \mathrm{M}$ glycine buffer, $\mathrm{pH}$ 2.0. Next, $75 \mu \mathrm{l} 1 \mathrm{M}$ Tris-base pH 9.0 were added to neutralize the acidic $\mathrm{pH}$ of the solution. After the selection, 76 phage clones were individually amplified in LB medium using sterile culture microplates (96-well microtest TM plate, BD Falcon TM clear, BD Biosciences, San Diego, California, USA). Sequencing was performed by capillary electrophoresis on the ABI 3130 equipment by BigDye v 3.1 and POP7 polymer (Myleus Biotechnology ${ }^{\oplus}$, Belo Horizonte, Minas Gerais, Brazil). A sequence scanner software (Applied Biosystems, Foster City, California, USA) was employed to analyze the AB1 output files. Of the 76 clones, 17 presented valid peptide sequences and were selected to stimulate PBMCs.

\section{PBMCs culture and cytokine assay}

PBMCs were purified from VL patients and healthy subjects by density centrifugation through Ficoll-Hypaque (GE Healthcare Bio-Sciences AB, Uppsala, Sweden). Cells $\left(10^{7}\right)$ were cultured in Roswell Park Memorial Institute
(RPMI) 1640 medium, which was supplemented with $20 \%$ inactivated fetal bovine serum (FBS, Sigma-Aldrich, St. Louis, Missouri, USA), $2 \mathrm{mM}$ L-glutamine, $200 \mathrm{U} / \mathrm{ml}$ penicillin, $100 \mu \mathrm{g} / \mathrm{ml}$ streptomycin, $50 \mu \mathrm{M} \quad 2$ mercaptoethanol, $1 \mathrm{mM}$ sodium pyruvate, and $1 \times$ nonessential amino acid. PBMCs were plated in 48-well flatbottomed tissue culture plates (Costar, Cambridge, MA, USA) and incubated in medium (control) or separately stimulated with the individual clones $\left(10^{10}\right.$ phages each) in a $5 \% \mathrm{CO}_{2}$ humidified atmosphere at $37^{\circ} \mathrm{C}$ for 5 days. $\mathrm{A}$ wild-type (WT) clone and a Random non-specific phage, which expressed a foreign peptide (GERQYFWYLSKK) that presented a lower than $30 \%$ similarity to Leishmania peptide sequences, were used as controls $\left(10^{10}\right.$ phages each). After, supernatants were collected, and IFN- $\gamma$ and IL-10 levels were measured by a capture enzyme-linked immunosorbent assay (ELISA), using commercial kits (Human IFN- $\gamma$ and IL-10 ELISA Sets, BD Biosciences, San Diego, California, USA) according to manufacturer's instructions. Results were interpolated from a standard curve using recombinant cytokines and expressed in $\mathrm{pg} / \mathrm{ml}$. After immunogenicity experiments, two clones, B1 and D11, were selected, based on their higher selectivity and specificity values, and were tested in the in vivo experiments.

\section{Bioinformatics assays}

The constrained Ph.D. library used for peptide selection presents conformational peptides with cysteine residues in the borders; therefore, analyses were performed using the 7-mer peptide sequence and the amino acid sequence (AC-XXXXXXX-CGGGS) contained in the fusion with the pIII bacteriophage capsid protein, as described elsewhere [32]. Sequences were deduced based on the nucleotides through the Expasy server (http:// web.expasy.org/translate/) and were analyzed by the Basic Local Alignment Search Tool (BLAST) program (http://blast.ncbi.nlm.nih.gov/Blast.cgi) against proteins and motifs of the GenBank database. The putative protein function was predicted by BLAST search alignment in the UNIPROT server (http://www.uniprot.org/). Physicochemical properties of B1 and D11 phage-exposed peptides, such as molecular weight, hydrophobicity, and net charge were predicted, using the Compute $\mathrm{pI} / \mathrm{Mw}$ tool (http://web.expasy.org/compute.pi/) and the antimicrobial peptide database server (http://aps.unmc.edu/ $\mathrm{AP} /$ prediction/prediction main.php).

\section{Parasite, immunization, and infection}

Leishmania infantum (MHOM/BR/1970/BH46) was used. Parasites were cultured at $24{ }^{\circ} \mathrm{C}$ in complete Schneider's medium (Sigma-Aldrich, St. Louis, Missouri, USA), which was added with 20\% FBS, $20 \mathrm{mM}$ L-glutamine, $200 \mathrm{U} / \mathrm{ml}$ penicillin, and $100 \mu \mathrm{g} / \mathrm{ml}$ streptomycin, 
$\mathrm{pH}$ 7.4. The soluble Leishmania antigenic extract (SLA) was prepared as described previously [33]. For the vaccination experiments, BALB/c mice ( $n=16$ per group) were inoculated subcutaneously in their left hind footpad with the WT, Random, B1, or D11 clones $\left(10^{10}\right.$ phages each) or received saline. Three doses were administered at 14-day intervals. 30 days after the last immunization, animals ( $n=8$ per group) were euthanized for the analysis of the immune response elicited by vaccination. At the same time, the remaining animals ( $n$ $=8$ per group) were infected subcutaneously in their right hind footpad with $10^{7} \mathrm{~L}$. infantum stationary-phase promastigotes and were followed up for 60 days.

\section{Parasite load by a limiting dilution assay and real-time polymerase chain reaction (RT-PCR)}

To evaluate the protection induced by the immunogens, the liver, spleen, draining lymph nodes (dLNs) and bone marrow (BM) of the infected and immunized animals were collected, and the parasite burden was evaluated by a limiting dilution technique, as described elsewhere [34]. Briefly, the organs were weighed and homogenized using a glass tissue grinder in sterile phosphate buffered saline (PBS). Tissue debris were removed by centrifugation at $150 \times g$, and cells were concentrated by centrifugation at $2000 \times g$. Pellets were re-suspended in $1 \mathrm{ml}$ of Schneider's medium together with $20 \%$ FBS, of which $220 \mu \mathrm{l}$ were plated onto 96-well flat-bottom microtiter plates (Nunc, Nunclon, Sigma-Aldrich, St. Louis, Missouri, USA) and diluted in log-fold serial dilutions, using supplemented Schneider's medium, to a $10^{-1}$ to $10^{-12}$ dilution. Each sample was plated in triplicate and read 7 days after the beginning of the culture, at $24{ }^{\circ} \mathrm{C}$.
Results were expressed as the parasites' percentage, which was normalized by the values obtained in the control (saline) group. The parasite load was also investigated in the animals' spleen by the real time-polymerase chain reaction (RT-PCR) technique, as described elsewhere [31]. Results were expressed by the number of parasites per 1000 nucleated cells in the experimental groups.

\section{Cellular and humoral response}

To evaluate the immunogenicity of the phage clones before and after infection, their spleen cells were plated in 24-well plates (Nunc), in duplicate. Cells $\left(5 \times 10^{6}\right)$ were incubated in RPMI 1640 medium or separately stimulated with each clone used in the immunization $\left(10^{10}\right.$ phages each) or L. infantum SLA $(25 \mu \mathrm{g} / \mathrm{ml})$, for $48 \mathrm{~h}$ at $37^{\circ} \mathrm{C}$ in $5 \% \mathrm{CO}_{2}$. IFN- $\gamma$, IL-4, IL-10, IL-12, and GM-CSF production was measured in the cell supernatant by using commercial kits (Pharmingen ${ }^{\circ}$ BD Biosciences, San Diego, California, USA), according to manufacturer's instructions. The nitrite production was investigated by the Griess reaction and results were expressed as micromolar. To evaluate the participation of $\mathrm{CD}^{+}$and $\mathrm{CD} 8^{+} \mathrm{T}$ cells in the IFN- $\gamma$ production, spleen cells of the animals of the B1 and D11-immunized groups were in vitro stimulated and incubated in the presence of monoclonal antibodies $(\mathrm{mAb})$ against mouse IL-12 (C017.8), CD4 (GK 1.5) or CD8 (53-6.7) $(5.0 \mu \mathrm{g} / \mathrm{ml}$, in all cases). Appropriate isotype-matched controls [rat IgG2a (R35-95) and rat IgG2b (95-1)] were used (Pharmingen ${ }^{\circ}, \mathrm{BD}$ Biosciences, San Diego, California, USA). The humoral response was investigated in the animals before and after infection. For this, sera samples were collected and phage and parasite-

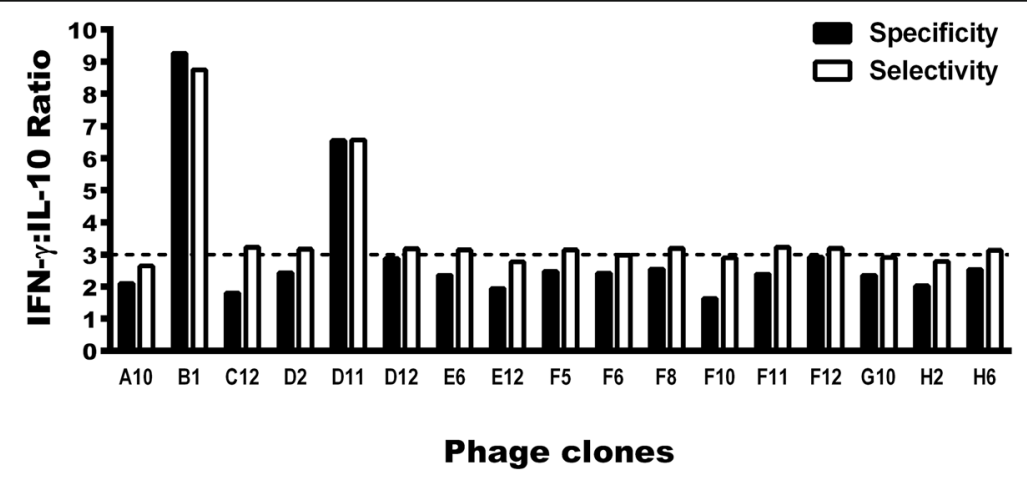

Fig. 1 Evaluation of selectivity and specificity of the phage clones. PBMCs were purified from blood samples from asymptomatic and symptomatic VL patients and non-infected subjects. Cells were non-stimulated (medium) or stimulated with each clone, as well as by Wild-type (WT) and Random clones ( $10^{10}$ phages each), for $48 \mathrm{~h}$ at $37^{\circ} \mathrm{C}$ in $5 \% \mathrm{CO}_{2}$. IFN- $\gamma$ and IL-10 levels were measured in the culture supernatants by an ELISA capture. Black bars indicate the specificity of the clones, which was calculated by dividing the IFN- $\gamma$ and IL-10 values obtained of each evaluated clone through respective values of these cytokines obtained after the WT phage stimulus, using PBMCs from healthy subjects. With the corrected values, the ratio between the IFN- $\gamma$ and IL-10 levels with these new results was calculated, and the specificity of the each clone was defined and is shown here. White bars indicate the selectivity, which was calculated by dividing the IFN- $\gamma$ and IL-10 values obtained of each evaluated clone through respective values of these cytokines obtained after the Random phage stimulus, using PBMCs from VL patients. With the corrected values, a ratio between the IFN- $\gamma$ and IL-10 levels with these new results was calculated, and the selectivity of each clone was defined and is shown here 
specific IgG1 and IgG2a antibody levels were measured by an ELISA technique, as described elsewhere [35].

\section{Flow cytometry}

A flow cytometry assay was performed in the spleen cells of the infected and immunized animals, aiming to evaluate the IFN- $\gamma$, TNF- $\alpha$ and IL-10-producing CD4 ${ }^{+}$ and $\mathrm{CD}^{+} \mathrm{T}$ cell frequency after stimulation using $L$. infantum SLA, as described elsewhere [36]. Results were expressed as indexes, which were calculated by dividing the cytokine-producing $\mathrm{CD}^{+}$and $\mathrm{CD}^{+} \mathrm{T}$ cell percentage in the stimulated cultures by the values obtained with unstimulated cultures (control).

\section{Cloning and purification of a hypothetical protein}

Bioinformatic assays indicated a Leishmania hypothetical protein as expressing the B1 phage-exposed peptide. In this context, this molecule (XP_001470472.1) was cloned using the genomic $L$. infantum DNA by PCR technique. The recombinant protein was expressed in an Escherichia coli M15 strain by adding $1.0 \mathrm{mM}$ isopropyl- $\beta$-Dthiogalactopyranoside (IPTG, Promega, Montreal, Canada) for $3 \mathrm{~h}$ at $37{ }^{\circ} \mathrm{C}$. For purification, bacteria were lysed and the product was centrifuged at $13,000 \times g$ for $20 \mathrm{~min}$ at $4{ }^{\circ} \mathrm{C}$. The recombinant protein (rLiHyp) was purified under non-denaturing conditions using a HisTrap column (GE Healthcare Life Science, Pittsburgh, USA), which was attached to a fast protein liquid chromatography (FPLC, GE Healthcare Life Science) system.

\section{ELISA experiments}

The recombinant Leishmania hypothetical protein (rLiHyp) was used in ELISA assays ( $0.5 \mu \mathrm{g}$ per well) in reaction to the B1 phage-vaccinated mice sera, as well as by those derived non-immunized (naive) mice, WT or Random-vaccinated animals (all 1:100 diluted in TBS-T). An anti-mouse IgG horseradish-peroxidase conjugated antibody (1:10,000 diluted in TBS-T) was used, and reactions were developed by incubation with a solution composed by $\mathrm{H}_{2} \mathrm{O}_{2}$, ortho-phenylenediamine and citratephosphate buffer, pH 5.0. The optical density (OD) values of the samples were read in an ELISA microplate spectrophotometer (Molecular Devices, Spectra Max Plus, Sunnyvale, California, USA) at $492 \mathrm{~nm}$ (nm).

\section{Immunoblotting assay}

To evaluate the specificity of the anti-B1 phage antibody to Leishmania proteins, an immunoblotting experiment using rLiHyp and L. infantum SLA was performed. For this, the recombinant protein and soluble antigenic extract (10 and $20 \mu \mathrm{g}$, respectively) were submitted to a $12 \%$ sodium dodecyl sulfate polyacrylamide gel (SDSPAGE) and blotted onto a nitrocellulose membrane (0.2 $\mu \mathrm{m}$ pore size, Sigma-Aldrich, St. Louis, Missouri,
USA). Next, membranes were blocked with TBS-T plus $5 \%$ bovine serum albumin (BSA) for $1 \mathrm{~h}$, and were independently incubated with pools of sera from nonimmunized mice $(n=6)$ or B1 phage-vaccinated animals $(n=6)$, all 1:100 diluted in TBS-T for $2 \mathrm{~h}$. As a secondary antibody, blots were incubated with peroxidase conjugated IgG anti-mouse (1:10,000; Sigma-Aldrich, St. Louis, Missouri, USA) for $2 \mathrm{~h}$. Reactions were developed by adding chloronaphtol, diaminobenzidine, and $\mathrm{H}_{2} \mathrm{O}_{2}$, and were stopped by adding distilled water.

\section{Statistical analysis}

The results were entered into Microsoft Excel (version 10.0) spreadsheets and analyzed by GraphPad Prism ${ }^{\mathrm{TM}}$

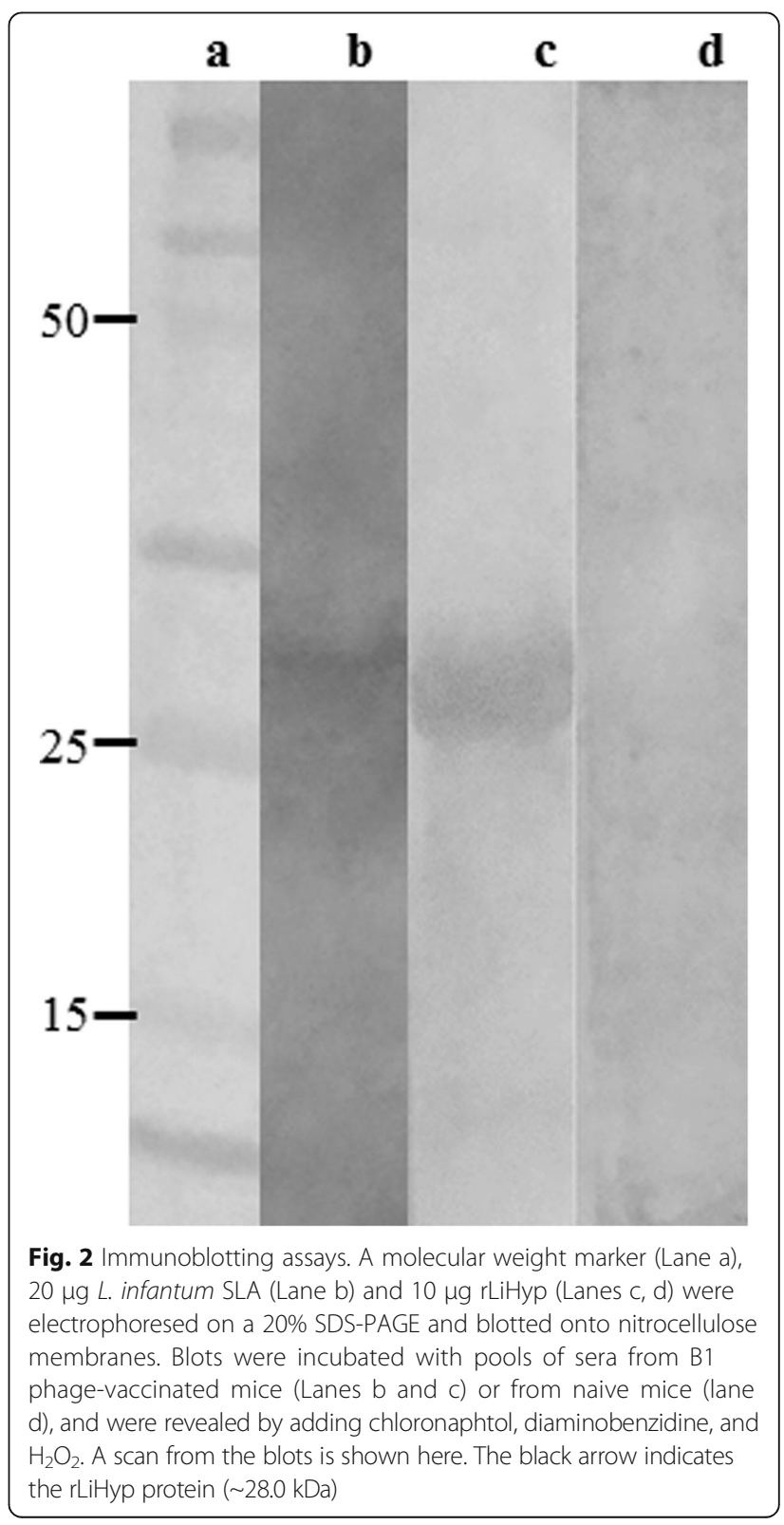


(version 6.0 for Windows). Statistical analyses were performed by one-way analysis of variance (ANOVA), followed by the Bonferroni's post-hoc test for comparisons between the groups. Differences were considered significant with $P<0.05$. The vaccination experiments were repeated and the results were similar between them. Data showed in this study are representative of the first experiment. Results obtained in the second study are shown in Additional file 1: Figure S1.

\section{Results}

\section{Selecting target clones by phage display and validating} them by means of immunological assays

In the present study, an experimental strategy using antibodies purified from the sera of non-infected subjects, as well as from asymptomatic and symptomatic VL patients, was performed, aiming to select new candidates to be tested as immunogens against disease. After three biopanning cycles, 76 clones were selected and sequenced, and 17 valid peptide sequences were deduced by the Expasy server. An alignment showed no consensus motif among sequences, and none of these were non-specific binders to the commons reagents used in the selection cycles (data not shown). The clones were then used to stimulate PBMCs from both non-infected subjects and VL patients, and IFN- $\gamma$ and IL-10 levels were measured in the cellular supernatants. As controls, WT and Random phages, as well as L. infantum SLA, were used to stimulate cells.

In an attempt to select the best immunogenic molecules, the specificity and selectivity were calculated for each one of the 17 clones, as compared to results obtained using the WT and Random phages as stimuli. An experimental strategy similar to this, developed by Costa et al. [23], was employed. For this, specificity was presented as the ability of each clone to bind to its target based on the presence of phage surface-displayed peptide. Values were calculated by determining the ratio between IFN- $\gamma$ and IL-10 levels, which were obtained after the stimulation of PBMCs from non-infected subjects through the respective values obtained using the WT phage stimulus. A new ratio was then calculated and results were defined as the specificity of each clone. The selectivity was presented as the ability of each clone to bind to its target based on the mixture of different molecules. Values were calculated by determining the ratio

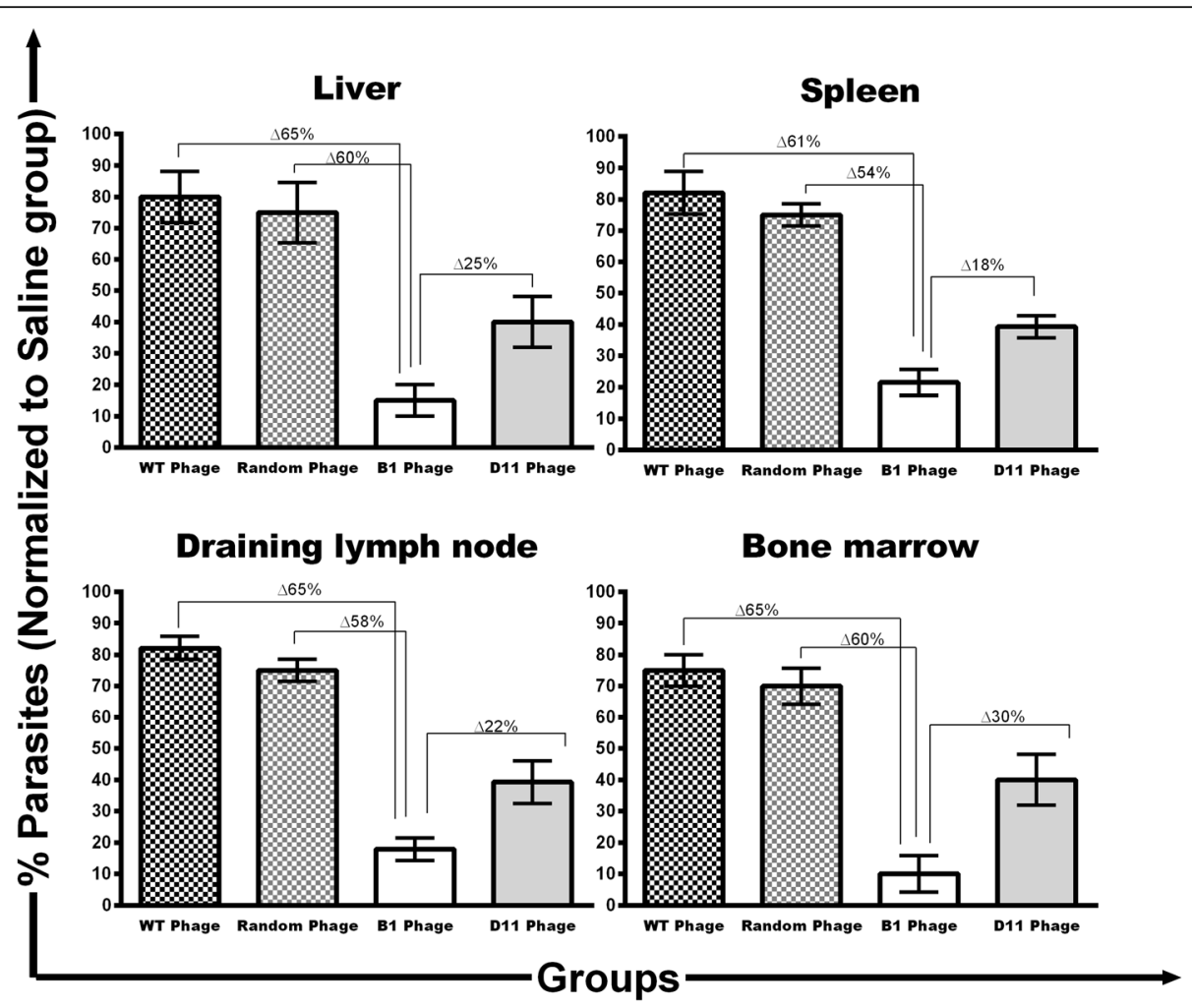

Fig. 3 Parasite burden in infected and vaccinated animals evaluated by a limiting dilution technique. BALB/c mice were immunized with the Wild-type (WT), Random, B1, or D11 phage clones and later infected with $10^{7} \mathrm{~L}$. infantum stationary promastigotes. The parasite loads from each group were normalized with the values found in the saline group. Results of the parasites' percentage in the liver, spleen, draining lymph nodes and bone marrow, as well as the differences between groups are shown. Bars represent the mean \pm standard deviation. Data shown in this study are representative of two independent experiments, which presented similar results 


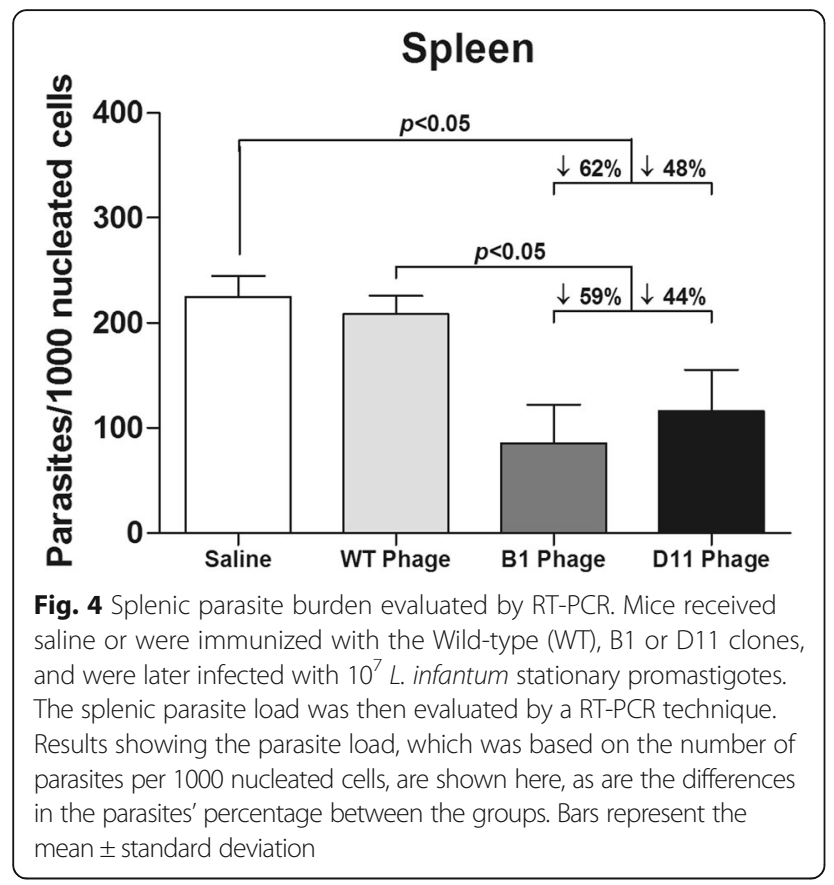

between the IFN- $\gamma$ and IL-10 levels, which were obtained after stimulation of PBMCs from VL patients through the respective values obtained using the Random phage stimulus. A new ratio was then calculated and results were defined as the selectivity of each clone. As a result, B1 and D11 clones presented ratios between IFN- $\gamma$ and IL-10 cytokines of higher than 3.0 and were selected to be tested in the in vivo experiments (Fig. 1).

Bioinformatics assays were used to evaluate the physicochemical properties of B1 and D11 clones, when net charge, molecular weight, and hydrophobicity were obtained: +1 and 0 ; 1396.6 and 1254.5; and 42 and 50\%, respectively. Using BLAST analyses to predict target peptides in Leishmania proteins, the B1 phage-exposed peptide proved to be present in a hypothetical protein (XP_001470472.1) and in the putative inositol polyphosphate kinase-like protein (XP_001464217.1), while the D11 phage-exposed peptide was identified in both the putative kinase protein (XP_001470438.1) and the permease protein (XP_003392714.1). To partially validate our findings through the application of bioinformatics, the hypothetical protein amino acid sequence (XP_001470472.1), which was identified as expressing the $\mathrm{B} 01$ mimotope, was cloned and its recombinant version (rLiHyp) was employed in ELISA and immunoblotting assays, in an attempt to verify the antigenicity of anti-B1 clone antibodies. Regarding ELISA experiments, high reactivity was found in the sera of B1 phageimmunized animals when the recombinant protein was used as an antigen in the plates. In this context, the mean \pm standard deviation of the OD values for the sera of these animals was of $0.550 \pm 0.044$, while the use of sera from naive, WT or Random phage-vaccinated mice presented the results of $0.022 \pm 0.04,0.040 \pm 0.008$ and $0.035 \pm 0.012$, respectively. An immunoblotting assay also showed that B1 phage-immunized animal sera reacted with $L$. infantum SLA and rLiHyp protein (Fig. 2), showing the specificity of the anti-B1 phage antibodies in recognizing this Leishmania protein.

\section{Immunization with B1 and D11 clones protect mice against $L$. infantum infection}

The B1 and D11 clones were administered in BALB/C mice, which were later challenged with $L$. infantum promastigotes. Sixty days after infection, the organs of the animals were collected and the parasite load was



Fig. 5 Cellular response before and after $L$. infantum infection. Splenocytes were obtained from the spleen of mice, 30 days after last immunization and 60 days after infection. Cells were stimulated with medium or stimulated with $\mathrm{L}$. infantum SLA $(25 \mu \mathrm{g} / \mathrm{ml})$, or with each clone $\left(10^{10}\right.$ phages) used in the immunization (group saline was stimulated with a phages mix), for $48 \mathrm{~h}$ at $37^{\circ} \mathrm{C}$ in $5 \% \mathrm{CO}_{2}$. IFN- $\gamma$, IL-12, GM-CSF, IL-4, and IL-10 levels were measured in culture supernatants by ELISA before (a) and after (b) infection. Bars represent the mean \pm standard deviation. ${ }^{* * *} P<0.0001$ (a statistically significant difference in relation to the saline, WT and Random groups). ${ }^{+++} P<0.0001$ (a statistically significant difference in relation to the B1 and D11 groups) 
evaluated by a limiting dilution technique. Vaccinated mice with B1 or D11 clones, when compared to the WT group, showed a significant reduction in the parasite percentage in the liver $(65 \%$ and $40 \%$ reductions, respectively) $\left(F_{(4,15)}=16.68, P<0.0001\right)$, spleen (61 and $43 \%$, respectively) $\left(F_{(4,15)}=33.36, P<0.0001\right)$, draining lymph nodes (dLN, 65 and 43\%, respectively) $\left(F_{(4,15)}=48.26, P<0.0001\right)$ and bone marrow $(\mathrm{BM}, 65$ and $35 \%$, respectively $)\left(F_{(4,15)}=19.44, \quad P<0.0001\right)$ (Fig. 3). When compared to the data from the Random phage group, B1 or D11 phages-immunized animals showed a significant reduction in parasite percentage in the liver (60 and 35\%, respectively)
$\left(F_{(4,15)}=16.68, \quad P<0.0001\right)$, spleen $(54$ and $36 \%$, respectively) $\quad\left(F_{(4,15)}=33.36, \quad P<0.0001\right), \quad \mathrm{dLN} \quad(58$ and $36 \%$, respectively) $\left(F_{(4,15)}=48.26, P<0.0001\right)$ and $\mathrm{BM}$ (60 and $30 \%$, respectively) $\left(F_{(4,15)}=19.44, P<0.0001\right)$. Data of parasite burden obtained in the second experiment are also shown (Additional file 1: Figure S1). Overall, B1 clone-immunized mice showed better protection in relation to the D11 phage. These data were corroborated by a RT-PCR assay, since immunization with B1 and D11 clones induced parasite percentage reductions in the spleen of the animals, as compared to data from saline, WT and Random groups (Fig. 4).

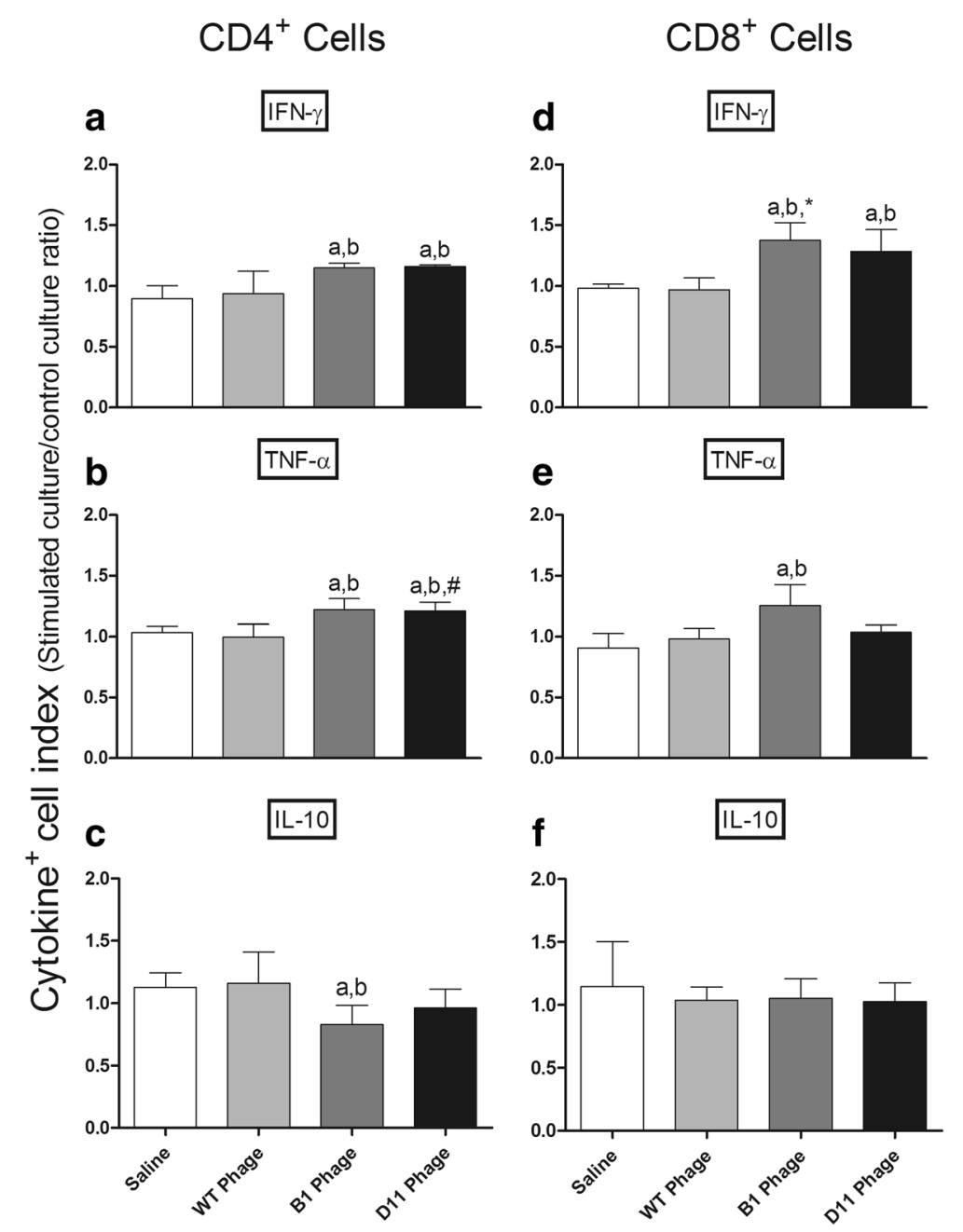

Fig. 6 Intracytoplasmic cytokine-producing T cell frequency after stimulus with L. infantum SLA. Cytokine indexes were calculated as the ratio of cytokine ${ }^{+}$cells observed in SLA-stimulated cultures divided by the control culture (SLA/CC ratio). Mice received saline (Saline: white rectangle), or were immunized with wild-type (WT Phage = light grey bars), B1 (B1 Phage $=$ dark grey bars) or D11 phages (D11 Phage = black bars). Later, they were challenged with $L$. infantum promastigotes and, 60 days after infection, their splenocytes were collected and in vitro stimulated with $L$. infantum SLA $(25 \mu \mathrm{g} / \mathrm{ml}$ ). Results were reported as cytokine indexes (Stimulated culture/Control culture ratio) for IFN- $\gamma$, TNF- $a$, and IL-10 in $\mathbf{a}$, $\mathbf{b}$ and $\mathbf{c}$, respectively, for $\mathrm{CD}^{+} \mathrm{T}$ cells and in $\mathbf{d}$, e and $\mathbf{f}$, respectively, for $\mathrm{CD} 8^{+} \mathrm{T}$ cells, and were expressed as mean plus standard deviation of the groups. Letters above bars indicate a statistically significant difference in relation to the saline and WT phage groups, respectively $(P<0.05)$; asterisk indicates a statistically significant difference between $\mathrm{CD}^{+}$and $\mathrm{CD} 4^{+} \mathrm{IFN}-\gamma^{+}$producing $T$ cells $\left({ }^{*} P<0.05\right.$ ); \# indicates a statistically significant difference between $\mathrm{CD}^{+}$and $\mathrm{CD} 8^{+} \mathrm{TNF}^{-\mathrm{a}^{+}}$producing $\mathrm{T}$ cells $(\# P<0.05)$ 
B1 and D11 phages-immunized mice develop a Th1 response before infection, which is maintained after challenge

The immunogenicity of B1 and D11 clones was evaluated in vaccinated mice 30 days after the last vaccine dose and before infection, as well as 60 days after challenge (Fig. 5). After in vitro stimulation with phages or L. infantum SLA, spleen cells from the animals of the B1 and D11 groups produced significantly higher levels of IFN- $\gamma\left(F_{(4,15)}=489.3, P<0.0001\right.$ and $F_{(4,15)}=248.3, P$ $<0.0001$, respectively) and IL-12 $\left(F_{(4,15)}=382.3, \quad P<\right.$ 0.0001 and $F_{(4,15)}=31.24, P<0.0001$, respectively) than those from control mice. Low and insignificant levels of IL-4 $\left(F_{(4,15)}=17.48, P=0.0211 ; F_{(4,15)}=3.988, P=0.0213\right)$ and IL-10 $\left(F_{(4,15)}=31.06, P=0.0221 ; F_{(4,15)}=6.990, P=\right.$ 0.0222 ) were observed in all groups. After challenge, the Th1 immune profile was maintained in the B1 and D11 phage-vaccinated animals. However, mice from the control groups presented a higher production of IL- 4 and IL-10 towards a Th2 response profile (Fig. 5). Data of cellular response, which were obtained before and after infection in the second experiment, are also shown (Additional file 1: Figure S1). In addition, the intracytoplasmic cytokine response, which was evaluated by a flow cytometry, also showed that both B1 and D11vaccinated mice presented higher levels of antileishmanial IFN- $\gamma^{+}$and TNF- $\alpha^{+}$-producing $\mathrm{CD}^{+}$and $\mathrm{CD}^{+} \mathrm{T}$ cells, which were associated with a low presence of $\mathrm{IL}-10^{+} \mathrm{T}$ cells, when compared to results obtained in the saline, WT and Random groups (Fig. 6).

The involvement of $\mathrm{CD}^{+}$and $\mathrm{CD}^{+} \mathrm{T}$ cells in the phage and parasite-specific IFN- $\gamma$ production in $\mathrm{B} 1$ and D11 phage-vaccinated mice was also evaluated (Fig. 7). IFN- $\gamma$ levels were significantly decreased when both anti-CD4 $\left(F_{(2,9)}=198.0, P<0.0001\right)$ and anti-CD8 $\left(F_{(2,9)}\right.$ $=139.8, P<0.0001)$ monoclonal antibodies were used in the spleen cell cultures. It is important to note that IFN$\gamma$ production was higher after the application of the anti-CD4 antibody than after that of the anti-CD8 antibody in the vaccinated groups. The presence of IFN- $\gamma$ stimulates the production of $\mathrm{NO}$ and other molecules by phagocytic cells, thereby assisting in parasite control. In addition, GM-CSF, a cytokine related to macrophage activation and resistance in murine models against different Leishmania spp., is also required to protect against infection. To evaluate the macrophage activation in the infected and phage-vaccinated animals, GM-CSF and nitrite levels were measured in cell supernatants. In the results, significantly higher levels of GM-CSF $\left(F_{(4,15)}\right.$ $\left.=280.5, P<0.0001 ; F_{(4,15)}=207.9, P<0.0001\right) \quad($ Fig. $8 \mathrm{a})$ and nitrite $\left(F_{(4,15)}=59.58, P<0.0001 ; F_{(4,15)}=296.7, P<\right.$ 0.0001 ) (Fig. $8 \mathrm{~b}$ ) were observed in B1 and D11 phageimmunized mice, when compared to control groups, thus showing the importance of these molecules in the

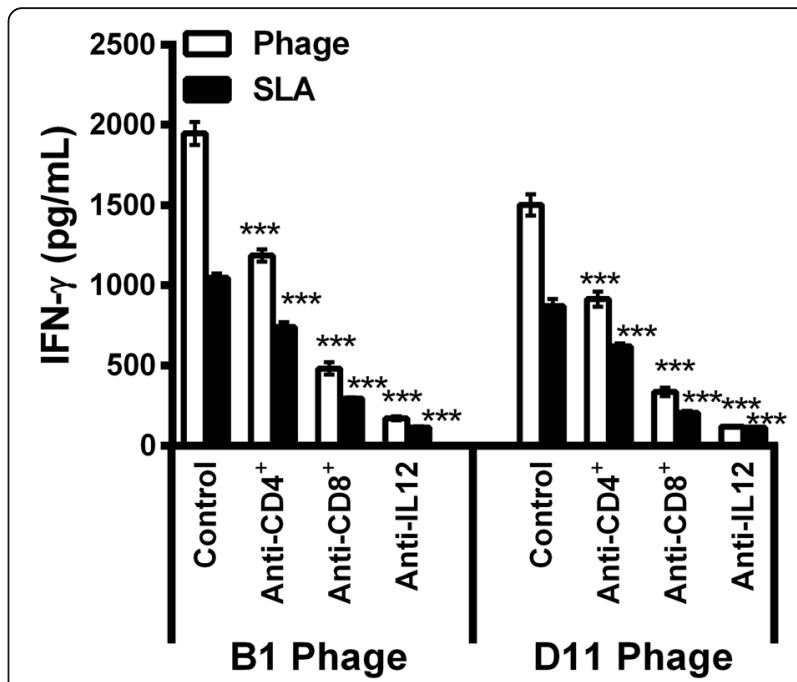

Fig. 7 Involvement of $\mathrm{CD}^{+}$or $\mathrm{CD}^{+} \mathrm{T}$ cells in IFN- $\gamma$ production. Spleen cells of mice that were immunized with B1 or D11 clones, and later infected, were in vitro stimulated with the respective clones $\left(1 \times 10^{10}\right.$ phages) or with SLA $(25 \mu \mathrm{g} / \mathrm{ml})$ for $48 \mathrm{~h}$ at $37^{\circ} \mathrm{C}$ in $5 \% \mathrm{CO}_{2}$. After, these were maintained in the absence (control) or incubated in the presence of monoclonal antibodies against mouse $\mathrm{IL}-12, \mathrm{CD}^{+}$or $\mathrm{CD}^{+}(5 \mu \mathrm{g} / \mathrm{ml}$ each). The IFN- $\mathrm{\gamma}$ production in the supernatants was evaluated, and the results are shown here. Bars represent the mean \pm standard deviation. ${ }^{* * *} P<0.0001$ (a statistically significant difference in relation to the control group)

control of the parasitism against Leishmania. The B1 and D11 phages-vaccinated mice exhibited a humoral response with a predominance of phage- and SLAspecific IgG2a isotype, when compared to the IgG1 levels found before and after infection. Results shown as ratios between IgG2a and IgG1 levels demonstrate that mice from the B1 and D11-vaccinated groups presented a higher IgG2a/IgG1 ratio, whereas animals from the saline, WT and Random groups showed a mixed IgG2a/ IgG1 profile, with values near of 1.0 (Fig. 9). Data of humoral response, which were obtained before and after infection in the 2nd experiment, are also shown (Additional file 1: Figure S1).

\section{Discussion}

In recent decades, several antigens, such as A2 [37], nucleoside hydrolase $(\mathrm{NH}) 36$ [38], ribosomal proteins [35, 39] and cyclophilin [40] among others, have been considered candidates to produce a protective vaccine against leishmaniasis. Despite the large number of molecules tested and vaccination protocols employed, no effective vaccine against human disease has been achieved. As a consequence, new candidates based on phageexposed peptides have been successfully identified by phage display, thus resulting in new diagnostic markers, vaccine candidates, and/or immunotherapeutic targets against diseases [41-44]. In this light, our research 


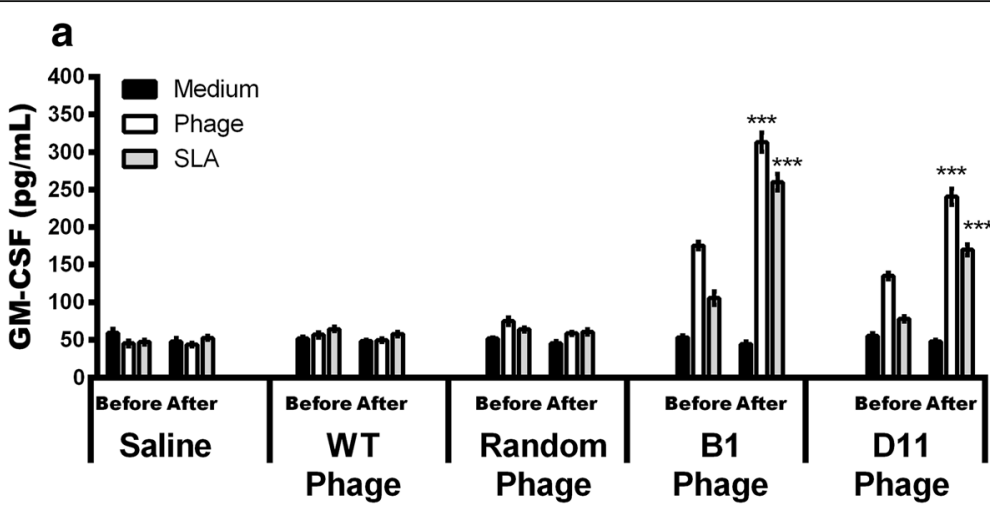

b

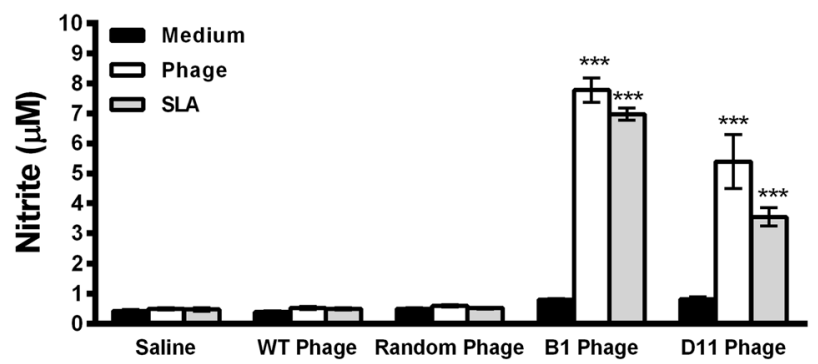

Fig. 8 Macrophage activation in the infected and vaccinated animals. Spleen cells from mice that received saline or were immunized with wildtype (WT), Random, B1 or D11 phage clones, and later infected with L. infantum promastigotes, were in vitro stimulated with SLA ( $25 \mu \mathrm{g} / \mathrm{ml})$ or with the respective clone $\left(1 \times 10^{10}\right.$ phages) for $48 \mathrm{~h}$ at $37^{\circ} \mathrm{C}$ in $5 \% \mathrm{CO}_{2}$. The GM-CSF production (a) was evaluated in the vaccinated (Before) as well as in the infected (After) animals, whereas the nitrite secretion (b) was evaluated after infection. Bars represent the mean \pm standard deviation. ${ }^{* *} P<0.0001$ (a statistically significant difference in relation to the saline, WT and Random groups)

group has successfully applied this technology to select new candidates for serodiagnosis $[23,45]$ and as vaccine candidates $[46,47]$ against canine VL.

The development of a human vaccine against leishmaniasis is possible, since approximately $80 \%$ of $L$. dono$v a n i$-infected patients clear their parasites spontaneously before developing the active disease, and they present protective immunity against reinfection [46]. In addition, nearly $85 \%$ of all treated and cured VL patients showed resistance against $L$. donovani reinfection $[47,48]$. The current study has proposed a new strategy to identify phage-displayed peptides as immunogens to be tested as vaccine candidates against VL by mimicking the immune response of asymptomatic patients and subjects living in endemic areas of the disease. Here, new targets were selected by the cytokine profile (i.e. a polarized Th1 response, as evidenced by higher IFN- $\gamma /$ IL-10 ratio) induced in human PBMCs from asymptomatic VL patients and non-infected individuals. These were successfully tested in an in vivo murine model against experimental infection by the parasite.

The selection strategy used to identify new immunogenic targets based on phage molecules can be considered valid, since these products are not infective or pathogenic to mammalian hosts, but they do replicate inside the host cells, improving the quality and intensity of the generated immune response [49]. In addition, phage-exposed peptides are robust, stable to harsh conditions and highly immunogenic, and present five copies in each viral particle, in a population of millions of phages, but without interfering in the infectivity of these agents [50-53]. Moreover, the production of the compounds is considered easier and cheaper, when compared to the synthesis of peptides or production of recombinant proteins [54].

Adjuvants are defined as molecules able to activate the innate immunity receptors expressed in the antigenpresenting cells of the mammalian hosts, which take up and present the antigens to $\mathrm{T}$ helper cells, improving the efficacy of the antigen-specific response [55]. Most studies evaluating vaccine candidates against leishmaniasis used recombinant molecules associated with Th1-type adjuvants [56-60]. However, the use of such products presents disadvantages, mainly due to the low number of compounds available and licensed for human use, in addition to the higher cost of production of the vaccine formulation. However, in the current study, no adjuvant was added to the B1 and D11 clones, since the phage molecule is able to stimulate through the development of a Th1 response primed by the production of IFN- $\gamma$ 


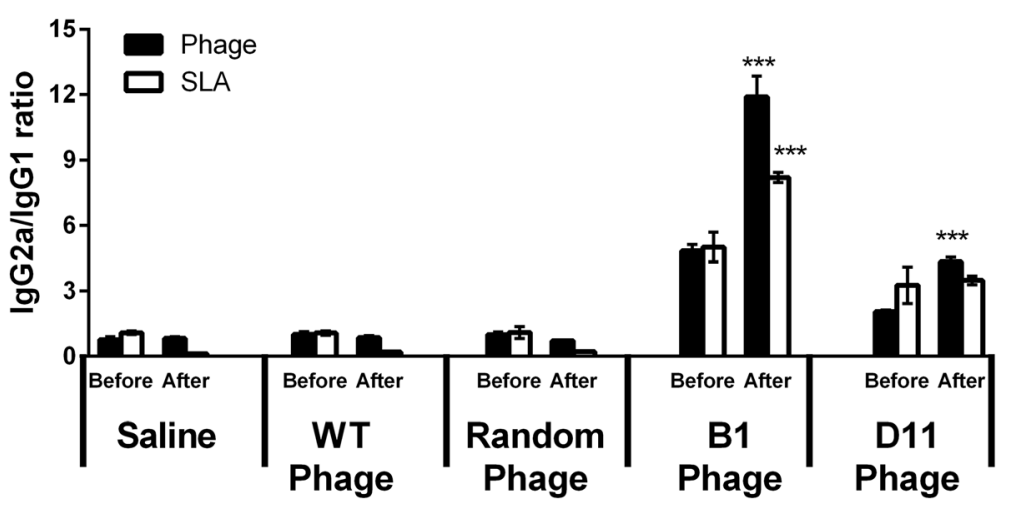

Fig. 9 Phage and parasite-specific humoral response before and after infection. BALB/c mice received saline or were immunized with Wild-type (WT), Random, B1 or D11 clones. Thirty days after the last immunization, sera samples were collected (Before). In addition, remaining animals were challenged with $L$. infantum promastigotes and followed up for 60 days, at which time sera samples were collected (After). The anti-phage and anti-parasite lgG2a and lgG1 isotype antibody levels were obtained, and the ratios between lgG2a and lgG1 results were calculated and are shown here. Bars represent the mean \pm standard deviation. ${ }^{* * *} P<0.0001$ (a statistically significant difference in relation to the saline, WT and Random groups)

and IL-12 due to the presence of stimulatory nonmethylated cytosine-phosphate-guanosine (CpG) motifs in their viral genome, which activate the immune system of the mammalian hosts through Toll-like receptors [52, 61-64].

We have successfully shown the protective efficacy of B1 and D11 clones against L. infantum infection in the immunized mice, compared to control groups, including WT phage and a Random phage-fused mimotope. Since phages displaying peptides can induce humoral and cellmediated immune responses without the need for an adjuvant, results obtained here show the development of a specific Th1 response in the B1 and D11 phagevaccinated animals, which was maintained after infection. Indeed, spleen cells of vaccinated mice mounted an in vitro specific production of IFN- $\gamma$, IL-12 and GMCSF, which was combined with low levels of IL-4 and IL-10, in addition to the predominance of parasitespecific IgG2a antibodies. This immunogenic effect was reflected by protection against $L$. infantum infection, since significant reductions in the parasite burden in different organs was reached, when compared to the control groups, thus showing the efficacy of these immunogens in protecting against challenge infection.

Understanding the factors mediating protective immunity against leishmaniasis, and whether the immune response can be mediated by memory $\mathrm{T}$ cells, will contribute to a long-term protection against parasite infection by means of the generation of long-lasting protective vaccines, since naturally acquired resistance to reinfection by Leishmania coincides with an ongoing primary infection. Studies have shown that $\mathrm{T}$ cells presenting functional attributes of memory cells are maintained in the absence or low presence of parasites, and this fact could represent long-lasting protection against reinfection [65]. In the present study, immunological memory induced by immunization using the B1 and D11 phages was not evaluated in the vaccinated animals. However, this procedure will be conducted in future works in an attempt to investigate the protective potential of these immunogens in animals against a more long-lasting infection. These aspects will certainly contribute to an improved design for vaccine candidates with respect to their ability to raise memory response, aiming to improve their protective performance against L. infantum infection.

\section{Conclusions}

The present study's data pointed out the immunological applications of B1 and D11 clones as vaccine candidates against VL. The employment of products able to offer protection against disease added support to further investigation, thus employing both phage clones and focusing on the perspectives of the rational improvement of the vaccine formulation, which might have a positive impact upon the management of this important but relevant and neglected disease.

\section{Additional file}

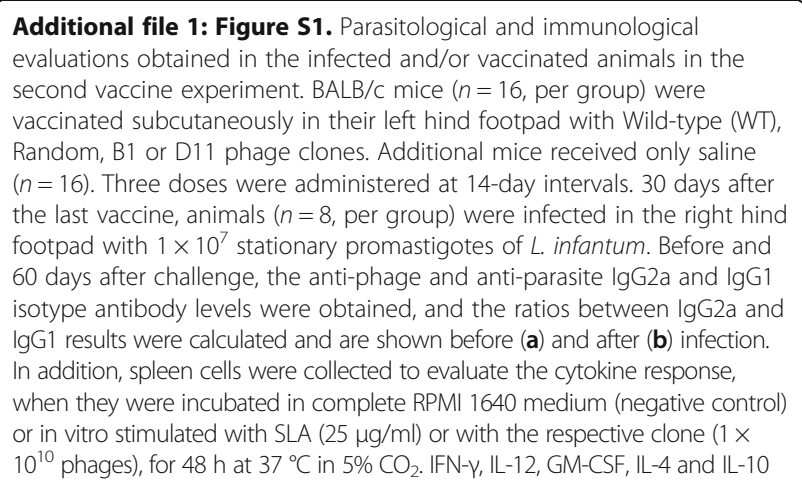


levels were then measured by ELISA in the culture supernatants before (c) or after (d) infection. 6 days after challenge, the parasite burden was determined in the liver, spleen, draining lymph nodes and bone marrow of the animals, by a limiting dilution assay (e). Using the cell supernatants employed to evaluate cytokines, the nitrite production was also evaluated in this time (f). ${ }^{+}$indicates a statistically significant difference in relation to the B1 and D11 phages groups $(P<0.0001)$. ${ }^{* * *}$ indicates a statistically significant difference in relation to the saline, WT and Random groups $(P<0.0001)$. (TIFF $139 \mathrm{~kb})$

\section{Abbreviations}

BLAST: Basic Local Alignment Search Tool; BM: Bone marrow; DLNs: Draining lymph nodes; ELISA: Enzyme-linked immunosorbent assay; FBS: Fetal bovine serum; FPLC: Fast protein liquid chromatography; GM-CSF: Granulocytemacrophage colony-stimulating factor; IFN- $\gamma$ : Interferon-gamma; IgG: Immunoglobulin G; IL: Interleukin; IPTG: Isopropyl- $\beta$-Dthiogalactopyranoside; KDNA: Kinetoplastid deoxyribonucleic acid; MRNA: Messenger ribonucleic acid; $\mathrm{NH}$ : Nucleoside hydrolase; Nm: Nanometers; NO: Nitric oxide; OD: Optical density; PBMCs: Peripheral blood mononuclear cells; RLiHyp: Recombinant Leishmania hypothetical protein; RT-PCR: Real-time polymerase chain reaction; SDS-PAGE: Sodium dodecyl sulfate polyacrylamide gel; SLA: Soluble Leishmania antigenic extract; TGF- $\beta$ : transforming growth factor beta; Th: T helper; TNF-a: tumor necrosis factor-alpha; VL: Visceral leishmaniasis; WT: Wild-type

\section{Acknowledgements}

Dr Carlos Alberto Pereira Tavares of the Department of Biochemistry and Immunology, Federal University of Minas Gerais is thanked for scientific comments on the manuscript.

\section{Funding}

This work was supported by grants from the Pró-Reitoria de Pesquisa da Universidade Federal de Minas Gerais (Edital 02/2017), Instituto Nacional de Ciência e Tecnologia em Nanobiofarmacêutica (INCT Nano-Biofar), National Institute of Science and Technology in Theranostics and Nanobiotechnology (CNPq/CAPES/FAPEMIG, Process No. 465669/2014-0), FAPEMIG (CBB-APQ00819-12 and CBB-APQ-01778-2014) and CNPq (APQ-482976/2012-8, APQ488237/2013-0 and APQ-467640/2014-9). EAFC, ALT and LRG are grant recipients of CNPq. MACF is a grant recipient of CAPES/FAPEMIG.

\section{Availability of data and materials}

All data supporting the conclusions of this article are included within the article and its additional file.

\section{Authors' contributions}

EAFC, LRG and ALT conceived and designed the experiments. FFR, LEC, DSD, TTOS, MRR, DPL, BCSS, VTM, PAFR, ACSD, PTA, BMR, DMS and MCD performed the experiments. EAFC, ALT, LRG, MACF and PTA analyzed the data. ALT and ELMV contributed reagents/materials/analysis tools. EAFC, ALT and LRG wrote the paper. All authors read and approved the final manuscript.

\section{Ethics approval and consent to participate}

This study was approved by Research Ethics Committee from Federal University of Minas Gerais (UFMG, Belo Horizonte, Minas Gerais, Brazil), under protocol number CAAE-323431 14.9.0000.5149. A written informed consent was obtained from all subjects, who received an individual copy of the study policy, which was reviewed by an independent person. For experiments using mice, studies were carried out in strict accordance with the Brazilian guidelines and recommendations on animal experimentation and welfare. In this context, all procedures were approved by the UFMG Committee on the Ethical Handling of Research Animals, logged under protocol number 333/2015.

\section{Consent for publication}

Not applicable.

\section{Competing interests}

The authors declare that they have no competing interests.

\section{Publisher's Note}

Springer Nature remains neutral with regard to jurisdictional claims in published maps and institutional affiliations.

\section{Author details}

${ }^{1}$ Programa de Pós-Graduação em Ciências da Saúde: Infectologia e Medicina Tropical, Faculdade de Medicina, Universidade Federal de Minas Gerais, Av. Prof. Alfredo Balena, 190, Belo Horizonte, Minas Gerais 30130-100, Brazil. 'Laboratório de Nanobiotecnologia, Instituto de Genética e Bioquímica, Universidade Federal de Uberlândia, Av. Amazonas s/n, Campus Umuarama, Bloco 2E, Sala 248, Uberlândia, Minas Gerais 38400-902, Brazil. '²aboratório Interdisciplinar de Investigação Médica, Faculdade de Medicina, Universidade Federal de Minas Gerais, Av. Prof. Alfredo Balena, 190, Belo Horizonte, Minas Gerais 30130-100, Brazil. ${ }^{4}$ Departamento de Patologia Clínica, COLTEC, Universidade Federal de Minas Gerais, Av. Antônio Carlos, 6627, Pampulha, Belo Horizonte, Minas Gerais 31270-901, Brazil. ${ }^{5}$ Neuropsychiatry Program, Department of Psychiatry and Behavioral Sciences, McGovern Medical School, The University of Texas Health Science Center at Houston, 1941 East Road, Houston, TX 77041, USA. ${ }^{6}$ Department of Medical Microbiology and Immunology, University of California-Davis, Davis, CA 95616, USA.

Received: 18 August 2017 Accepted: 6 December 2017

Published online: 21 December 2017

\section{References}

1. Kaye P, Scott P. Leishmaniasis: complexity at the host-pathogen interface. Nat Rev Microbiol. 2011;9:604-15.

2. Bates PA, Depaquit J, Galati EA, Kamhawi S, Maroli M, McDowell MA, et al. Recent advances in phlebotomine sand fly research related to leishmaniasis control. Parasit Vectors. 2015;8:131.

3. Silveira FT, Lainson R, Castro-Gomes CM, Laurenti MD, Corbett CE. Immunopathogenic competences of Leishmania (V.) braziliensis and L. (L.) amazonensis in American cutaneous leishmaniasis. Parasite Immunol. 2009; 31:423-31.

4. Sharma M, Shaikh N, Yadav S, Singh S, Garg P. A systematic reconstruction and constraint-based analysis of Leishmania donovani metabolic network: identification of potential antileishmanial drug targets. Mol BioSyst. 2017;13:955-69.

5. Chávez-Fumagalli MA, Ribeiro TG, Castilho RO, Fernandes SO, Cardoso VN, Coelho CS, et al. New delivery systems for amphotericin B applied to the improvement of leishmaniasis treatment. Rev Soc Bras Med Trop. 2015:48:235-42.

6. Agallou M, Smirlis D, Soteriadou KP, Karagouni E. Vaccination with Leishmania histone $\mathrm{H} 1$-pulsed dendritic cells confers protection in murine visceral leishmaniasis. Vaccine. 2013;30:5086-93.

7. Kumar R, Nylén S. Immunobiology of visceral leishmaniasis. Front Immunol. 2012;3:251.

8. Kumar R, Engwerda C. Vaccines to prevent leishmaniasis. Clin Transl Immunol. 2014;3:e13.

9. Pakpour N, Zaph C, Scott P. The central memory CD4 ${ }^{+} \mathrm{T}$ cell population generated during Leishmania major infection requires IL-12 to produce IFNgamma. J Immunol. 2008;180:8299-305.

10. Gannavaram S, Bhattacharya P, Ismail N, Kaul A, Singh R, Nakhasi HL. Modulation of innate immune mechanisms to enhance Leishmania vaccineinduced immunity: role of co-inhibitory molecules. Front Immunol. 2016;7:18

11. White ACJ, Castes M, Garcia L, Trujillo D, Zambrano L. Leishmania chagasi antigens recognized in cured visceral leishmaniasis and asymptomatic infection. Am J Trop Med Hyg. 1992;46:123-31.

12. Gidwani K, Rai M, Chakravarty J, Boelaert M, Sundar S. Evaluation of leishmanin skin test in Indian visceral leishmaniasis. Am J Trop Med Hyg 2009:80:566-7.

13. Ansari NA, Kumar R, Gautam S, Nylén S, Singh OP, Sundar S, et al. IL-27 and IL-21 are associated with T cell $I L-10$ responses in human visceral leishmaniasis. J Immunol. 2011;186:3977-85.

14. Iborra S, Parody N, Abánades DR, Bonay P, Prates D, Novais FO, et al. Vaccination with the Leishmania major ribosomal proteins plus CpG oligodeoxynucleotides induces protection against experimental cutaneous leishmaniasis in mice. Microbes Infect. 2008;10:1133-41.

15. Goto Y, Bhatia A, Raman VS, Liang H, Mohamath R, Picone AF, et al. KSAC, the first defined polyprotein vaccine candidate for visceral leishmaniasis. Clin Vaccine Immunol. 2011;18:1118-24. 
16. Agallou M, Smirlis D, Soteriadou KP, Karagouni E. Vaccination with Leishmania histone $\mathrm{H1}$-pulsed dendritic cells confers protection in murine visceral leishmaniasis. Vaccine. 2012;30:5086-93.

17. Baharia RK, Tandon R, Sharma T, Suthar MK, Das S, Siddiqi Ml, et al. Recombinant NAD-dependent SIR-2 protein of Leishmania donovani: immunobiochemical characterization as a potential vaccine against visceral leishmaniasis. PLoS Negl Trop Dis. 2015;9:e0003557.

18. Lage DP, Martins VT, Duarte MC, Garde E, Chávez-Fumagalli MA, MenezesSouza D, et al. Prophylactic properties of a Leishmania-specific hypothetical protein in a murine model of visceral leishmaniasis. Parasite Immunol. 2015; 37:646-56.

19. Bazan J, Całkosiñski I, Gamian A. Phage display: a powerful technique for immunotherapy: 1. Introduction and potential of therapeutic applications. Hum Vaccine Immunother. 2012;8:1817-28.

20. Prudencio $C R$, Nascimento R, Filho MM, Marra AO, Souza GR, Almeida JF, et al. In silico analysis for identification of tick phagotopes selected by phagedisplayed libraries. Rev Bras Parasitol Vet. 2009;18:39-41.

21. Aghebati-Maleki L, Bakhshinejad B, Baradaran B, Motallebnezhad M, Aghebati-Maleki A, Nickho $\mathrm{H}$, et al. Phage display as a promising approach for vaccine development. J Biomed Sci. 2016;23:66.

22. Dong J, Otsuki T, Kato T, Kohsaka T, Ike K, Park EY. Development of two murine antibodies against Neospora caninum using phage display technology and application on the detection of N. Caninum. PLoS One. 2013;8:e53264

23. Costa LE, Lima MIS, Chávez-Fumagalli MA, Menezes-Souza D, Martins VT, Duarte MC, et al. Subtractive phage display selection from canine visceral leishmaniasis identifies novel epitopes that mimic Leishmania infantum antigens with potential serodiagnosis applications. Clin Vaccine Immunol. 2014;21:96-106.

24. Trigo G, Martins TG, Fraga AG, Longatto-Filho A, Castro AG, Azeredo J, et al. Phage therapy is effective against infection by Mycobacterium ulcerans in a murine footpad model. PLoS Negl Trop Dis. 2013;7:e2183.

25. Adhya S, Merril CR, Biswas B. Therapeutic and prophylactic applications of bacteriophage components in modern medicine. Cold Spring Harb Perspect Med. 2014:4:a012518.

26. Goulart LR, Vieira CU, Freschi AP, Capparelli FE, Fujimura PT, Almeida JF, et al. Biomarkers for serum diagnosis of infectious diseases and their potential application in novel sensor platforms. Crit Rev Immunol. 2010;30: 201-22.

27. Frenkel D, Katz O, Solomon B. Immunization against Alzheimer's betaamyloid plaques via EFRH phage administration. Proc Natl Acad Sci USA. 2000;97:11455-9.

28. Manoutcharian K, Díaz-Orea A, Gevorkian G, Fragoso G, Acero G, González E, et al. Recombinant bacteriophage-based multiepitope vaccine against Taenia solium pig cysticercosis. Vet Immunol Immunopathol. 2004;99:11-24.

29. Costa LE, Goulart LR, Pereira NC, Lima MI, Duarte MC, Martins VT, et al. Mimotope-based vaccines of Leishmania infantum antigens and their protective efficacy against visceral leishmaniasis. PLoS One. 2014;9: e110014.

30. Costa LE, Chávez-Fumagalli MA, Martins VT, Duarte MC, Lage DP, Lima MI, et al. Phage-fused epitopes from Leishmania infantum used as immunogenic vaccines confer partial protection against Leishmania amazonensis infection. Parasitology. 2015;142:1335-47.

31. Salles BC, Costa LE, Alves PT, Dias AC, Vaz ER, Menezes-Souza D, et al. Leishmania infantum mimotopes and a phage-ELISA assay as tools for a sensitive and specific serodiagnosis of human visceral leishmaniasis. Diagn Microbiol Infect Dis. 2017:87:219-25.

32. Alves PT, Fujimura PT, Morais LD, Goulart LR. Revisiting the CD14: epitope mapping by phage display. Immunobiology. 2014;219:822-9.

33. Martins VT, Lage DP, Duarte MC, Carvalho AM, Costa LE, Mendes TA, et al. A recombinant fusion protein displaying murine and human $\mathrm{MHC}$ class $\mathrm{I}$ - and II-specific epitopes protects against Leishmania amazonensis infection. Cell Immunol. 2017;313:32-42.

34. Martins VT, Chávez-Fumagalli MA, Costa LE, Canavaci AMC, Martins AMCC, Lage PS, et al. Antigenicity and protective efficacy of a Leishmania amastigote-specific protein, member of the super-oxygenase family, against visceral leishmaniasis. PLoS Negl Trop Dis. 2013;7:e2148.

35. Chávez-Fumagalli MA, Costa MA, Oliveira DM, Ramírez L, Costa LE, Duarte $M C$, et al. Vaccination with the Leishmania infantum ribosomal proteins induces protection in BALB/C mice against Leishmania chagasi and Leishmania amazonensis challenge. Microbes Infect. 2010;12:967-77.
36. Martins VT, Lage DP, Duarte MC, Costa LE, Garde E, Rodrigues MR, et al. A new Leishmania-specific hypothetical protein, LiHyT, used as a vaccine antigen against visceral leishmaniasis. Acta Trop. 2016;154:73-81.

37. Coelho EAF, Tavares CA, Carvalho FA, Chaves KF, Teixeira KN, Rodrigues RC, et al. Immune responses induced by the Leishmania (Leishmania) donovani A2 antigen, but not by the LACK antigen, are protective against experimental Leishmania (Leishmania) amazonensis infection. Infect Immun. 2003;71:3988-94.

38. Aguilar-Be I, Zardo RS, Paraguai-de-Souza E, Borja-Cabrera GP, RosadoVallado M, Mut-Martin M, et al. Cross-protective efficacy of a prophylactic Leishmania donovani DNA vaccine against visceral and cutaneous murine leishmaniasis. Infect Immun. 2005;73:812-9.

39. Ramirez L, Villén LC, Duarte MC, Chávez-Fumagalli MA, Valadares DG, Santos DM, et al. Cross-protective effect of a combined L5 plus L3 Leishmania major ribosomal protein based vaccine combined with a Th1 adjuvant in murine cutaneous and visceral leishmaniasis. Parasit Vectors. 2014:2:3-10.

40. Santos-Gomes GM, Rodrigues A, Teixeira F, Carreira J, Alexandre-Pires G, Carvalho $\mathrm{S}$, et al. Immunization with the Leishmania infantum recombinant cyclophilin protein 1 confers partial protection to subsequent parasite infection and generates specific memory T cells. Vaccine. 2014;32:1247-53.

41. Smith GP. Filamentous fusion phage: novel expression vectors that display cloned antigens on the virion surface. Science. 1985;228:1315-7.

42. Larralde OG, Martinez R, Camacho F, Amin N, Aguilar A, Talavera A, et al. Identification of hepatitis a virus mimotopes by phage display, antigenicity and immunogenicity. J Virol Methods. 2007;140:49-58.

43. Manhani MN, Ribeiro VS, Cardoso R, Ueira-Vieira C, Goulart LR, Costa-Cruz JM. Specific phage-displayed peptides discriminate different forms of neurocysticercosis by antibody detection in the serum samples. Parasite Immunol. 2011;33:322-9.

44. Feliciano ND, Ribeiro VS, Santos FA, Fujimura PT, Gonzaga HT, Goulart $L R$, et al. Bacteriophage-fused peptides for serodiagnosis of human strongyloidiasis. PLoS Negl Trop Dis. 2014;8:e2792

45. Costa LE, Salles BC, Alves PT, Dias AC, Vaz ER, Ramos FF, et al. New serological tools for improved diagnosis of human tegumentary leishmaniasis. J Immunol Methods. 2016:434:39-45.

46. Ostyn B, Gidwani K, Khanal B, Picado A, Chappuis F, Singh SP, et al. Incidence of symptomatic and asymptomatic Leishmania donovani infections in high-endemic foci in India and Nepal: a prospective study. PLoS Negl Trop Dis. 2011;5:e1284.

47. Zijlstra EE, Musa AM, Khalil EAG, El Hassan IM, El-Hassan AM. Post-kala-azar dermal leishmaniasis. Lancet Infect Dis. 2003;3:87-98.

48. Vijayamahantesh, Amit A, Dikhit MR, Singh AK, Venkateshwaran T, VNR D, et al. Immuno-informatics based approaches to identify $\mathrm{CD}^{+} \mathrm{T}$ cell epitopes within the Leishmania donovani 3-ectonucleotidase in cured visceral leishmaniasis subjects. Microbes Infect. 2017;19:358-69.

49. Cui J, Ren HJ, Liu RD, Wang L, Zhang ZF, Wang ZQ. Phage-displayed specific polypeptide antigens induce significant protective immunity against Trichinella spiralis infection in BALB/c mice. Vaccine. 2013;6:1171-7.

50. Duarte MC, Lage DP, Martins VT, Costa LE, Lage LM, Carvalho AM, et al. A vaccine combining two Leishmania braziliensis proteins offers heterologous protection against Leishmania infantum infection. Mol Immunol. 2016;76:70-9.

51. Gu Y, Li J, Zhu X, Yang J, Li Q, Liu Z, et al. Trichinella spiralis: characterization of phage-displayed specific epitopes and their protective immunity in BALB/c mice. Exp Parasitol. 2008;118:66-74.

52. Gaubin M, Fanutti C, Mishal Z, Durrbach A, Berardinis P, Sartorius R, et al. Processing of filamentous bacteriophage virions in antigen-presenting cells targets both HLA class I and class II peptide loading compartments. DNA Cell Biol. 2003;22:11-8.

53. Hashiguchi S, Yamaguchi Y, Takeuchi O, Akira S, Sugimura K. Immunological basis of M13 phage vaccine: regulation under MyD88 and TLR9 signaling. Biochem Biophys Res Commun. 2010;402:19-22.

54. Duarte MC, Lage DP, Martins VT, Chávez-Fumagalli MA, Roatt BM, MenezesSouza D, et al. Recent updates and perspectives on approaches for the development of vaccines against visceral leishmaniasis. Rev Soc Bras Med Trop. 2016:49:398-407.

55. Pereira L, Abbehusen M, Teixeira C, Cunha J, Nascimento IP, Fukutani K, et al. Vaccination with Leishmania infantum acidic ribosomal PO but not with nucleosomal histones proteins controls Leishmania infantum infection in hamsters. PLoS Negl Trop Dis. 2015;9:e0003490. 
56. Thakur A, Kaur H, Kaur S. Studies on the protective efficacy of freeze thawed promastigote antigen of Leishmania donovani along with various adjuvants against visceral leishmaniasis infection in mice. Immunobiology. 2015;220:1031-8.

57. Coler RN, Duthie MS, Hofmeyer KA, Guderian J, Jayashankar L, Vergara J, et al. From mouse to man: safety, immunogenicity and efficacy of a candidate leishmaniasis vaccine LEISH-F3+GLA-SE. Clin Transl Immunol. 2015:4:e35.

58. Mason KA, Ariga H, Neal R, Valdecanas D, Hunter N, Krieg AM, et al. Targeting toll-like receptor 9 with CPG oligodeoxynucleotides enhances tumor response to fractionated radiotherapy targeting toll-like receptor 9 with CPG oligodeoxynucleotides enhances tumor response to fractionated radiotherapy. Clin Cancer Res. 2005;11:361-9.

59. Fernandes AP, Costa MMS, Coelho EAF, Michalick MSM, Freitas E, Melo MN, et al. Protective immunity against challenge with Leishmania (Leishmania) chagasi in beagle dogs vaccinated with recombinant A2 protein. Vaccine. 2008;26:5888-95.

60. Handman E. Leishmaniasis: current status of vaccine development. Clin Microbiol Rev. 2001;14:229-43.

61. Szalai K, Jensen-Jarolim E, Pali-Schöll I. Vaccination strategies based on the mimotope concept. G Ital Dermatol Venereol. 2008;143:95-104.

62. Van Houten NE, Zwick MB, Menendez A, Scott JK. Filamentous phage as an immunogenic carrier to elicit focused antibody responses against a synthetic peptide. Vaccine. 2006;24:4188-200.

63. Vijayamahantesh AA, Kumar S, Dikhit MR, Jha PK, Singh AK, et al. Upregulation of $\mathrm{A} 2 \mathrm{~B}$ adenosine receptor on monocytes are crucially required for immune pathogenicity in Indian patients exposed to Leishmania donovani. Cytokine. 2015;79:38-44.

64. Houimel M, Dellagi K. Peptide mimotopes of rabies virus glycoprotein with immunogenic activity. Vaccine. 2009;27:4648-55.

65. Selvapandiyan A, Dey R, Gannavaram S, Lakhal-Naouar I, Duncan R, Salotra $P$, et al. Immunity to visceral leishmaniasis using genetically defined liveattenuated parasites. J Trop Med. 2012;2012:631460.

\section{Submit your next manuscript to BioMed Central and we will help you at every step:}

- We accept pre-submission inquiries

- Our selector tool helps you to find the most relevant journal

- We provide round the clock customer support

- Convenient online submission

- Thorough peer review

- Inclusion in PubMed and all major indexing services

- Maximum visibility for your research

Submit your manuscript at www.biomedcentral.com/submit

) Biomed Central 